\title{
Cyst Reduction by Melatonin in a Novel Drosophila Model of Polycystic Kidney Disease
}

\author{
Cassandra Millet-Boureima ${ }^{1}$, Roman Rozencwaig ${ }^{2}$, Felix Polyak ${ }^{2}$ and Chiara Gamberi ${ }^{1, *(D)}$ \\ 1 Biology Department, Concordia University, Montreal, QC H4B 1R6, Canada; \\ cassandra.millet@mail.concordia.ca \\ 2 BH Bioscience, Montreal, QC H3W 2L2, Canada; rachmilr@gmail.com (R.R.); rcq003@gmail.com (F.P.) \\ * Correspondence: chiara.gamberi@concordia.ca; Tel.: +1-514-848-2424 (ext. 3395)
}

Academic Editor: Dun-Xian Tan

Received: 21 October 2020; Accepted: 20 November 2020; Published: 23 November 2020

\begin{abstract}
Autosomal dominant polycystic kidney disease (ADPKD) causes progressive cystic degeneration of the renal tubules, the nephrons, eventually severely compromising kidney function. ADPKD is incurable, with half of the patients eventually needing renal replacement. Treatments for ADPKD patients are limited and new effective therapeutics are needed. Melatonin, a central metabolic regulator conserved across all life kingdoms, exhibits oncostatic and oncoprotective activity and no detected toxicity. Here, we used the Bicaudal C (BicC) Drosophila model of polycystic kidney disease to test the cyst-reducing potential of melatonin. Significant cyst reduction was found in the renal (Malpighian) tubules upon melatonin administration and suggest mechanistic sophistication. Similar to vertebrate PKD, the BicC fly PKD model responds to the antiproliferative drugs rapamycin and mimics of the second mitochondria-derived activator of caspases (Smac). Melatonin appears to be a new cyst-reducing molecule with attractive properties as a potential candidate for PKD treatment.
\end{abstract}

Keywords: polycystic kidney disease; renal cysts; melatonin; Drosophila; longevity; oxidative stress

\section{Introduction}

\subsection{Polycystic Kidney Disease}

Autosomal dominant polycystic kidney disease (ADPKD) is a genetic disease affecting 12.5 million people globally. ADPKD typically causes the progressive formation of cysts all along the renal tubules called nephrons [1]. ADPKD has been linked to mutations in the PKD1 gene in about $80 \%$ of the cases and in PKD2 in about $15 \%$ of patients, with the residual $\sim 5 \%$ of cases remaining genetically unknown or linked to rare mutations in other loci [1]. Renal cystic disease in general, and ADPKD particularly, display complex metabolic alterations in the tissue of the renal tubule [2] as well as impaired fluid transport [1]. As cysts progressively grow, they compress and damage the surrounding renal parenchyma, impairing the neighboring nephrons, both cystic and non-cystic. The ensuing reduced renal function eventually leads to renal failure in one patient out of two [1].

Cystic growth in ADPKD displays some neoplastic characteristics [3,4]. Among several cancer pathways found to be dysregulated in ADPKD [5-16], activation of the mechanistic/mammalian target of rapamycin (mTOR) pathway was found to contribute to renal cyst cell proliferation in patients and ADPKD animal models [6,17-21]. As well, myc, a common oncogene elevated in cancer cells, was found to be upregulated in ADPKD [21-23]. Murine ADPKD models have helped to define the stages of disease progression, as well as study the effects of mutations [24]. These studies clearly indicated that the genetics of ADPKD-type cyst formation is complex. The discovery that human PKD1 and its murine ortholog affect the expression of the gene BICAUDAL $C$, which in turn regulates MYC and mTOR has 
allowed to place BICAUDAL C genetically downstream of PKD1 and upstream of MYC [21]. Originally discovered in the fruit fly Drosophila melanogaster ovary, the Bicaudal $C$ gene encodes for the prototype of a family of RNA binding proteins (reviewed in [25]). The human BICAUDAL C gene is abbreviated as BICC1, the murine one as Bicc1, and the Drosophila one as BicC. Adult BicC mutant flies display key ADPKD features [21]. In ADPKD patients, cysts occur most frequently in the intermediate and terminal (distal) regions of the renal tubule [1]. Similarly, in the BicC mutant flies, cysts occur most frequently in the intermediate and terminal tubules [21]. Cyst occurrence in the terminal tubules is thought to disrupt fluid readsorption and urine concentration that normally occur in this region [1]. Similar to ADPKD, BicC mutant flies also display TOR activation and myc upregulation [21]. Drosophila has thus joined the arsenal of PKD-type cyst models to study the genetic underpinning of renal cystogenesis [21]. The fly features conservation of $75 \%$ of genes and pathways involved in human disease [26]. Renal pathway components are also highly conserved (reviewed in [27,28]). The Drosophila aglomerular renal system contains four anatomically separate renal (Malpighian) tubules analogous to the tubular regions of the human nephron. Reminiscent of nephron diversity in the human kidneys, each fly contains one pair of longer Malpighian tubules extending anteriorly and one pair of shorter ones oriented posteriorly. Such anterior and posterior pairs have distinct transcriptomes and functions [29]. Also similar to the human nephron, each fly Malpighian tubule displays functionally distinct regions with selective transport. In the fly, these are called proximal, intermediate, and terminal (reviewed in [27]). Unlike the human nephron, the Drosophila Malpighian tubules can be precisely dissected and examined to evaluate cyst-reducing molecules $[27,30,31]$.

A mimetic of the second mitochondria-derived activator of caspases (Smac) was shown to ameliorate cysts in a murine ADPKD model [32]. Using the Drosophila BicC PKD model, we have recently characterized the substantial cyst-reducing properties of four novel Smac mimetics confirming a potential for Smac mimicry in ameliorating PKD, which further underscores conservation of the renal cystic mechanisms [30]. ADPKD is incurable, urging the discovery of anti-cystic drugs. A repurposed antagonist of the vasopressin V2 receptor, tolvaptan has been approved for use in a subset of ADPKD patients between the ages of 18 and 50, presenting a moderate decline in renal function, as well as fast disease progression $[33,34]$. Tolvaptan-induced hepatotoxicity and possible loss of efficacy over time limit its broad use in PKD therapy [34]. In an effort to offer remedy to the larger ADPKD patient population, several molecules and diet-induced strategies targeting altered cystic cell metabolism are being studied (e.g., [35-37]). Unlike several antineoplastic compounds, such molecules exhibit low general toxicity and may present wider applicability. In fact, because ADPKD is chronic and must be managed in the long-term, an ideal ADPKD drug would have no to low toxicity.

\subsection{Melatonin}

Melatonin ( $\mathrm{N}$-acetyl-5-methoxytrypamine) is a ubiquitous neurohormone that, in humans, is produced and secreted at night from the pineal gland and is also made locally by cells in the brain [38,39], skin [40], gastrointestinal tract [41], lymphocytes [42], several other tissues, and potentially all cells [43]. Melatonin is thought to function pleiotropically to synchronize most physiological functions with the circadian cycle (reviewed in [44]). In mammalians, melatonin acts via $G$ protein-coupled receptors MT1 and MT2, which are ubiquitously expressed in the central nervous system [45-49]. Other melatonin receptors may also exist, and melatonin may also function in receptor-independent ways (reviewed in [50]). Melatonin reduces oxidative stress, anxiety, hypertension [51-53] and pain [54]. Melatonin has been found to extend the lifespan of rodents and fruit flies, while treating age-related diseases such as premature aging and carcinogenesis [49,53,55-59].

Consistent with its numerous physiological effects, melatonin has long been known as an oncostatic in a variety of cancer types and is thought to function at multiple levels $([58]$; reviewed in $[60,61])$. Melatonin reduces proliferation of several cancer cells in vitro, e.g., breast [62-68], melanoma [69,70] via several growth factor pathways (e.g., insulin, TOR, mitogen activated protein kinases, MAPK, epithelial growth factor, EGF [71-76]; reviewed in [61]) and regulates energy production via the insulin 
pathway, nutrient uptake and glycolysis (ib.). Melatonin exerts anti-genotoxic, anti-mutagenic and anti-oxidative effects in vitro and in vivo, while bringing reactive oxidative species to toxic levels specifically in cancer cells [56,58,77-91]. Simultaneously, melatonin can induce cancer cell apoptosis and cell death via multiple pathways [51,75,92-94]. Moreover, melatonin was found to suppress angiogenesis by inhibiting the abnormal proliferation and migration of endothelial cells ([68,95-97]; reviewed in [98]) and to play immunomodulatory functions (reviewed in [61]). One notable ADPKD feature is the hyperproliferation of the tubular epithelium to form cysts through the activation of evolutionarily conserved pathways ([3,4,99], reviewed in [16]). Moreover, ADPKD causes oxidative stress and inflammation [100-102]. The cellular pathways of reactive oxidative response are conserved in Drosophila [103-106].

Considering the wide and potentially beneficial effects of melatonin, as well as its low toxicity profile [107-109], we tested the cyst-reducing potential of melatonin utilizing the Drosophila PKD model. The BicC fly model of renal cystogenesis was previously used successfully to test the anti-cystic activity of rapamycin [21] and Smac mimetics [30]. Here, we report that melatonin was found to substantially reduce cysts in the Drosophila PKD model.

\section{Results}

\subsection{Melatonin Significantly Reduced Cysts in the Renal Tubule of Bic $\mathrm{C}^{\Delta / \mathrm{YC} 33}$ Mutants}

Populations of BicC $C^{\triangle Y C 33}$ flies aged 0-2 days were fed either vehicle (ethanol) or $150 \mu \mathrm{M}$ melatonin and treated in parallel (Figure 1). When compared to the vehicle-treated siblings, $150 \mu \mathrm{M}$ melatonin significantly reduced cysts in both the anterior and posterior tubules of the milder Bic $\mathrm{C}^{\triangle Y Y C 33}$ flies $(n=50)$ by $36 \%$ (total 529 vs. 340 cysts, $p=0.0029)$ and $31 \%$ (total 551 vs. 412 cysts, $p=0.0117$ ), respectively (Table 1, Figure 2).

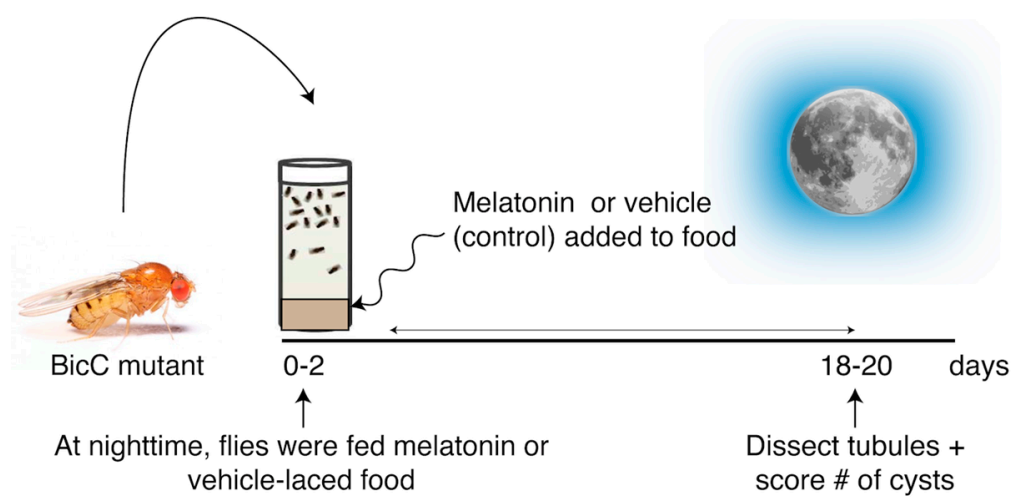

Figure 1. Protocol for testing the melatonin anti-cystic activity. Bic $C^{\triangle Y C 33}$ and BicC $C^{\Delta / I F 34}$ flies (aged 0-2d) were placed in food-containing vials mixed with either vehicle (ethanol) or $150 \mu \mathrm{M}$ melatonin at nighttime. Malpighian tubules were micro-dissected after 18 days of treatment and cysts scored (population aged 18-20d).

Table 1. Overall cyst reduction upon melatonin treatment of BicC mutants.

\begin{tabular}{ccc}
\hline & Anterior Tubules & Posterior Tubules \\
\hline $\operatorname{Bic}^{\Delta / Y C 33}(n=50)$ & $\mathbf{3 6 \%}(p=0.0029)$ & $\mathbf{3 1 \%}(p=0.017)$ \\
$\operatorname{Bic}^{\Delta / I I F 34}(n=50)$ & $18 \%(n . s)$. & $7 \%(n . s)$. \\
\hline
\end{tabular}

Bold indicates significant cyst reduction; Italics indicate populations yielding $p>0.05$ (statistically not significant, $n . s$.).

\subsection{Melatonin Treatment Displayed Regional Specificity in BicC $\mathrm{C}^{\Delta \mathrm{YC} 33}$ Mutants}

Similar to human nephrons, the Drosophila renal tubules display regional specialization and differential response to Smac mimics [30]. Thus, we examined the regional physiological response 
to melatonin treatment. In the Bic $C^{\triangle Y C 33}$ flies, melatonin appeared to reduce cysts in the proximal, intermediate, and terminal regions of the anterior tubules, respectively, by 59, 37 and 31\% (total 27 vs. 11 cysts ( $p=0.0389), 306$ vs. 193 cysts $(p=0.0031)$, and 196 vs. 136 cysts $(p=0.0152)$ ) (Table 2, Figure 2). In the posterior tubules, melatonin administration diminished cysts in the proximal, intermediate and terminal regions, respectively, by 12,30 and $25 \%$ (total 101 vs. 89 cysts ( $p=0.3493$ ), 271 vs. 189 cysts $(p=0.0070)$, and 179 vs. 134 cysts $(p=0.0454))$ (Table 2 , Figure 2$)$.

a.

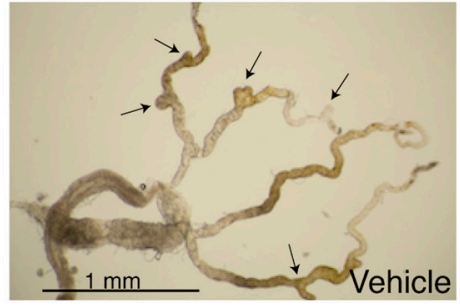

b.

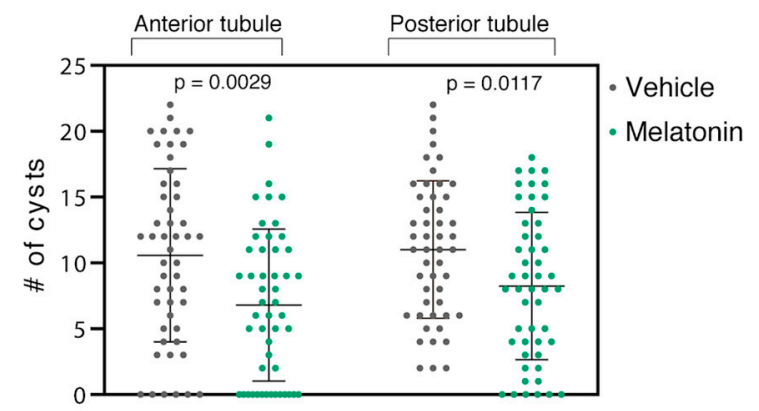

c.

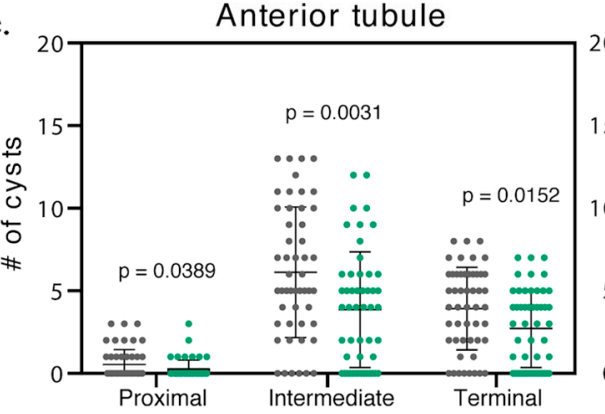

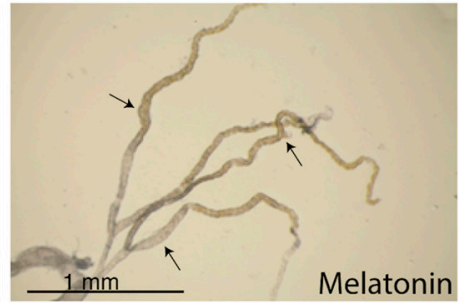

Melatonin

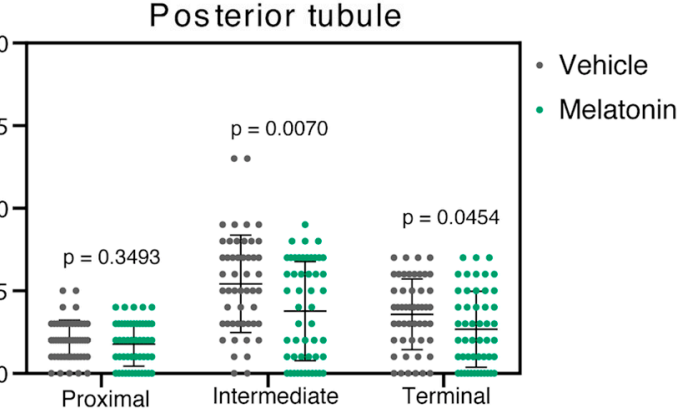

Figure 2. Melatonin reduced cysts in the renal tubule of $B i c C^{\Delta / Y C 33}$ flies. (a) Representative Malpighian tubules micro-dissected from Bic $C^{\Delta / Y C 33}$ flies treated with either vehicle (ethanol) or $150 \mu \mathrm{M}$ melatonin were photographed ex vivo. Arrows indicate exemplary cysts. (b) Nested plots reporting overall number of cysts found in each anterior and posterior tubule pair of 50 vehicle- and 50 melatonin-treated cystic flies, with mean and standard deviation. (c) Regional analyses. Nested plots indicating the number of cysts found in the proximal, intermediate, and terminal region of the anterior and posterior tubule pairs of the flies in $b$, with mean and standard deviation. $p$ values (with Welch's correction) are indicated. Treatments are shown with color: vehicle, left, grey; melatonin, right, green. Melatonin treatment significantly reduced cysts in all regions of the Malpighian tubules of BicC ${ }^{\Delta Y C 33}$ flies $(p<0.05)$, except for the proximal region in the posterior tubules.

Table 2. Regional cyst reduction upon melatonin treatment of BicC mutants.

\begin{tabular}{ccccccc}
\hline & \multicolumn{3}{c}{ Anterior Tubules } & \multicolumn{3}{c}{ Posterior Tubules } \\
\cline { 2 - 7 } & Proximal & Intermediate & Terminal & Proximal & Intermediate & Terminal \\
\hline \multirow{2}{*}{ BicC $^{\Delta / Y C 33}$} & $\mathbf{5 9 \%}$ & $\mathbf{3 7 \%}$ & $\mathbf{3 1 \%}$ & $12 \%$ & $\mathbf{3 0 \%}$ & $\mathbf{2 5 \%}$ \\
& $p=0.0389$ & $p=0.0031$ & $p=0.0152$ & $p=0.3493$ & $p=0.0070$ & $p=0.0454$ \\
\hline \multirow{2}{*}{ BicC $^{\Delta / I F 34}$} & $7 \%$ & $21 \%$ & $16 \%$ & $2 \%$ & $9 \%$ & $7 \%$ \\
& $p=0.9051$ & $p=1296$ & $p=0.1798$ & $p=0.9013$ & $p=0.4891$ & $p=0.5161$ \\
\hline
\end{tabular}

Bold indicates significant cyst reduction; Italics indicate populations yielding $p>0.05$ (statistically not significant). 
Therefore, melatonin administration significantly reduced cysts in BicC $^{\triangle Y C 33}$ flies overall, with apparent slightly higher efficacy in the anterior tubule. Moreover, melatonin reduced cysts in the proximal, intermediate and terminal regions of the anterior tubules and in the intermediate and terminal regions of the posterior tubules, with the proximal region displaying a trend toward cyst reduction.

\subsection{Melatonin Treatment Was Less Efficient in BicC ${ }^{\Delta / I I F 34}$ Mutants}

The BicC allelic combination, BicC $\triangle / I I F 34$ yields more severe defects than BicC ${ }^{\triangle Y C 33}$ despite expressing higher levels of a truncated BicC protein [110] and may be a dominant negative [21]. Melatonin was administered to the $\operatorname{Bic}^{\Delta / I I F 34}$ flies $(n=50)$ with identical procedure. Melatonin induced an overall trend towards reduced cysts in both anterior and posterior tubules. However, phenotypic variability was such that $p$-values resulted above significance threshold. Specifically, compared to vehicle-treatment, the anterior tubule displayed 18\% less cysts (total 432 vs. 354 cysts, $p=0.1204$ ) and the posterior tubule $7 \%$ less (total 503 vs. 469 cysts, $p=0.5329$ ) (Table 1, Figure 3). Along the different regions of the Malpighian tubules of Bic $C^{\Delta / I I F 34}$ flies, melatonin administration also produced a trend in cyst-reduction in the proximal, intermediate, and terminal regions of the anterior tubules, respectively, by 7, 21 and 16\% (total 15 vs. 14 cysts ( $p=0.9051$ ), 217 vs. 172 cysts $(p=0.1296)$, and 200 vs. 168 cysts $(p=0.1798)$ ) (Table 2, Figure 3$)$. In the posterior tubules, melatonin diminished cysts in the proximal, intermediate and terminal regions by 2, 9 and 7\% (total 93 vs. 91 cysts $(p=0.9013), 206$ vs. 188 cysts $(p=0.4891)$, and 204 vs. 190 cysts $(p=0.5161)$ ) (Table 2, Figure 3 ). Therefore, melatonin administration yielded a trend in cyst reduction in the more severely cystic BicC $^{\triangle / I I F 34}$ flies; however, $p$-values remained above significance threshold.

a.
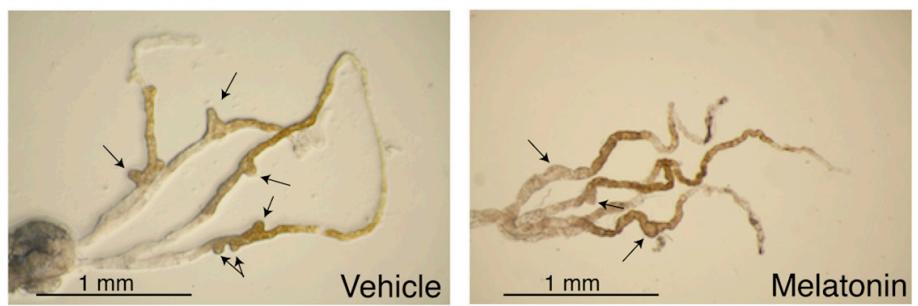

b.
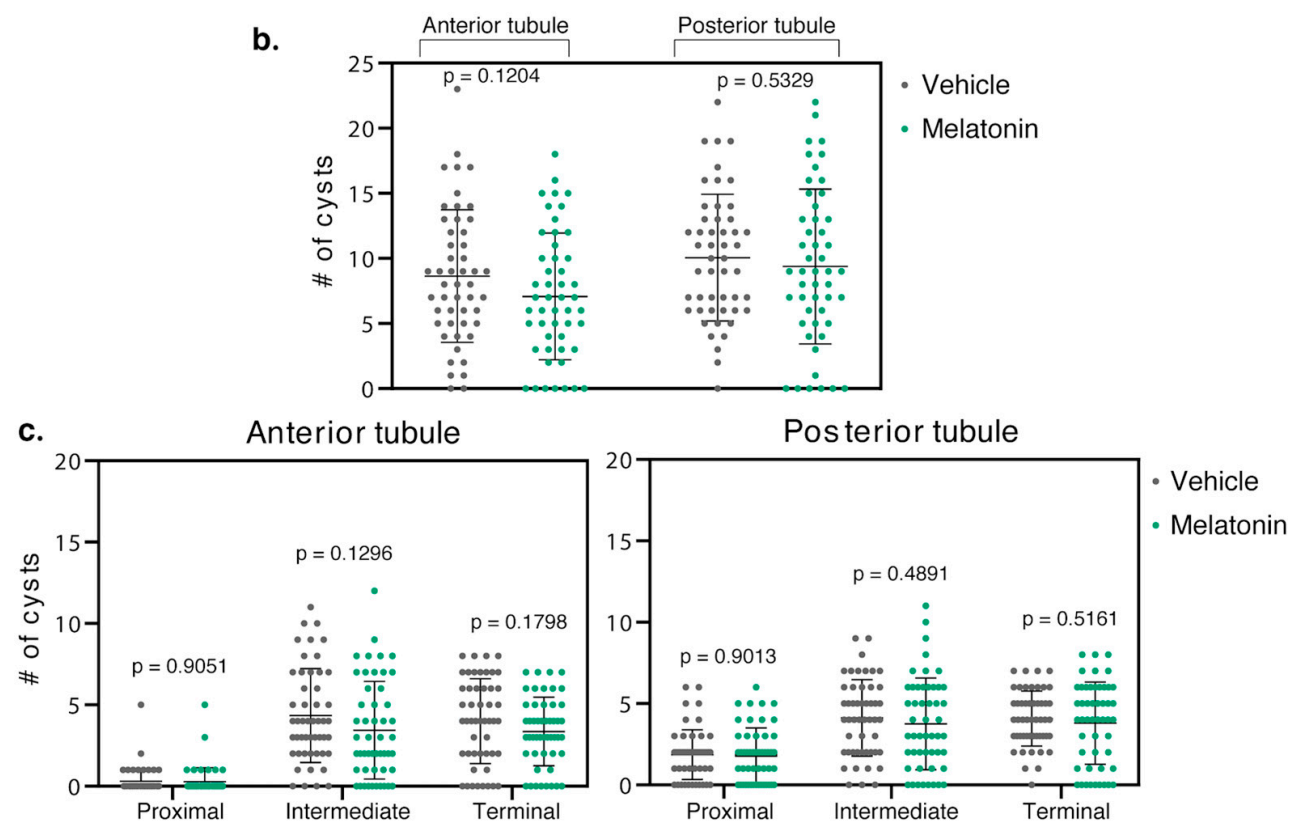

Figure 3. Melatonin did not reduce cysts in Bic $C^{\Delta / I F 34}$ flies. (a) Representative Malpighian tubules micro-dissected from Bic $C^{\Delta / I F 34}$ flies treated with either vehicle (ethanol) or $150 \mu \mathrm{M}$ melatonin were photographed ex vivo. Arrows indicate exemplary cysts. (b) Nested plots reporting overall number of 
cysts found in each anterior and posterior tubule pair of 50 vehicle- and 50 melatonin-treated cystic flies, with mean and standard deviation. (c) Regional analyses. Nested plots indicating the number of cysts found in the proximal, intermediate, and terminal region of the anterior and posterior tubule pairs of the flies in b, with mean and standard deviation. $p$ values (with Welch's correction) are indicated. Treatments are color-coded: vehicle, left, grey; melatonin, right, green. Melatonin treatment of $\mathrm{BicC}^{\Delta / I I F 34}$ flies produced a trend in cyst reduction, however, did not significantly differentiate the treated vs. untreated populations.

\section{Discussion}

Melatonin, a pleiotropic hormone, has long been studied for the treatment of age-related diseases and carcinogenesis. Suggesting a renoprotective role, decreased melatonin levels correlate with renal dysfunction in chronic kidney disease (CKD) [111-114]. Melatonin was found to protect rat kidneys against oxidative damage [115-117]. Upon carbon tetrachloride-induced oxidative damage, melatonin restored antioxidant enzyme levels and improved kidney histopathology [116]. Notably, diabetic and IgA nephropathies are characterized by increased circulating reactive oxygen species $[118,119]$. Early ADPKD pathogenesis has a strong component of oxidative stress [120] with reduced expression of antioxidant enzymes [100]. The reactive oxidative response is conserved in Drosophila [103-106,121-123]. Therefore, melatonin by lowering oxidative damage to the renal tubular cells, may similarly improve cysts in both mammalian and Drosophila renal tubules. Here, we report that melatonin exhibits cyst-reducing effects in the first-in-kind Drosophila model of PKD [21,27,30,31].

The BicC PKD fly model recapitulates phenotypic and molecular hallmarks of PKD1-induced PKD [21] and conserved pharmacological response to Smac mimetics [30]. In the mammalian response to pro-apoptotic signals and TNF- $\alpha$ /TNF receptor (TNFR) activation, the Smac protein is released from the mitochondria, which activates the caspase cascade [124]. Smac mimicry has been exploited in oncology to induce apoptosis in TNF- $\alpha$-dependent cancers $[125,126]$. Administration of small peptide mimetics of the Smac has been shown to be sufficient to activate the caspase cascade and mitigate cancer $[125,126]$. Both ADPKD patients and the $P k d 1^{-/}$mouse display high TNF- $\alpha$ amounts in the cystic fluid; moreover, the cystic cells feature higher-than-normal expression of the TNFR1 receptor. Unlike other tubular cells, the cyst-lining cells have abundant TNFR and are bathed in TNF- $\alpha$-rich fluid, which is thought to fuel an autoactivating loop promoting cyst growth [32,127]. Because of such specific and constitutive TNF- $\alpha$ activation in the cells of ADPKD cysts, one Smac mimetic has been tested in a murine model to preferentially eliminate cystic cells while sparing the non-cystic tubular portions [32]. TNF signaling is highly conserved in Drosophila [128-131]. We showed that, similar to the ADPKD mouse, administration of four novel Smac mimetics to the BicC fly PKD model significantly reduced cysts in the renal tubules [30]. This underscores the conservation of cystic pathways between human and Drosophila. Interestingly, melatonin has been shown to decrease TNF- $\alpha$ expression [132-135], which raises the possibility that melatonin pleiotropic functions may contribute to renal tubule normalization. In further support of this possibility, melatonin is a known antiproliferative that normalizes several overactive pathways in both cancer and ADPKD, e.g., ERK, mTOR, PI3K/Akt, PKC [1,16,53,58,71,136-143]. Note, the BicC fly model of PKD also exhibits hyperactive mTOR [21].

In 1861, it was reported that renal physiology has circadian rhythmicity [144]. Excretion of water, urea and electrolytes all follow 24-h cyclicity $[145,146]$. Defective glomerular filtration in patients with CKD may disturb sleep (reviewed in [113]). In end-stage renal disease (ESRD), the severity of insomnia appeared to correlate directly with disease progression [112], and inversely with melatonin levels [147-153]. While specific knowledge of the ADPKD situation is limited, deteriorating kidney function reduces circadian rhythm amplitude [112], suggesting that patients in late stage ADPKD may also have reduced melatonin level and/or function. Melatonin has only been tested in two small clinical trials to treat CKD-related sleep disturbances and the results of one such trials have been published [154]. Small trial NCT04336566 was designed to test melatonin effects on renal function in CKD, however, its results have not been made public. Melatonin pre-treatment has also been found to potentiate the 
beneficial anti-apoptosis, anti-oxidation, anti-inflammation effects of mesenchymal stem cell (MSC) therapy to treat acute kidney injury (AKI) and CKD ([155], reviewed in [156]). In a rat CKD model, melatonin pre-treated MSCs also reduced fibrosis in the kidney $[135,156]$. Together, this evidence strongly suggests that melatonin is crucial for maintaining proper kidney function and that nephrological diseases compromising renal capacity appear to upset the melatonin-dependent pathways.

In the Drosophila PKD model, nightly administration of $150 \mu \mathrm{M}$ melatonin efficiently reduced cysts in the Bic $C^{\triangle Y Y C 33}$ mutants, compared to vehicle-treated flies. These effects were observed both along the entire Malpighian tubules, and regionally. Melatonin reduced cysts in the anterior and posterior tubules by over $30 \%(p<0.012)$. In the terminal, intermediate and proximal regions of the anterior tubules of BicC $^{\Delta / Y C 33}$ flies, melatonin reduced cysts by $31-59 \%(p<0.039)$. In the posterior tubules, melatonin treatment reduced cysts in the terminal and intermediate regions by 25 and 30\% respectively $(p<0.045)$, while showing a trend towards reduction in the proximal region. Such differential response to melatonin is expected to be rooted onto the functional and physiological differences documented for the anterior and posterior tubules and the tubule regional specializations ([157]; reviewed in [27]). This property is also consistent with our previous observations of regionally distinct effects of Smac mimetics in the same PKD fly model [30]. In contrast to the Bic $C^{\Delta / Y C 33}$ mutants in which melatonin significantly reduced renal cysts, Bic $C^{\Delta / I F 34}$ flies only showed a trend of regional cyst reduction. Notably, the Bic $C^{\Delta / I F 34}$ genotype may be dominant negative [21]. This suggests that the genotype may influence the extent of melatonin response of the cystic renal tubule. Future investigations will decipher how melatonin may reduce renal cysts and how specific BicC mutations may affect the melatonin cyst-reducing activity in the renal tubule.

Several core cellular pathways are disrupted in ADPKD. As disease progresses, physiological compensation (e.g., through vasopressin signaling) compounds cellular changes [1]. The molecular detail of PKD pathology is largely unknown [24]. Melatonin biological activity as a potential ameliorator of PKD cystic pathology is intriguing. Firstly, its low toxicity is especially attractive for the long-term management of chronic PKD. Second, melatonin is a master cellular regulator conserved throughout evolution with pleiotropic functions that may help normalize several dysregulated pathways in PKD, e.g., oxidative stress, cell proliferation, fibrosis, renal circadian functions. Tolvaptan, a vasopressin V2 receptor antagonist, appears to primarily target vasopressin-dependent compensation in PKD through mechanisms conserved among mammals. Melatonin may potentially be combined with tolvaptan to reduce toxicity and treat PKD. In oncology, melatonin has been found to potentiate several chemotherapeutics, while simultaneously protecting the patient from their ill effects (e.g., [158-168]). If such property is conserved to its cyst-reducing activity, melatonin may become a prospective candidate for utilization as a single or combination drug in PKD therapy.

\section{Materials and Methods}

\subsection{Fly Lines and Husbandry}

BicC mutants were generated as in [21,30]. Briefly, virgin female flies harboring a BicC deletion in trans to the $\mathrm{CyO}$ balancer chromosome, $\mathrm{D} f(2 \mathrm{~L}) \mathrm{RA} 5 / \mathrm{CyO}$ (obtained from the Bloomington Drosophila Stock Center) were crossed with males carrying one of two hypomorphic $\mathrm{BicC}$ mutations in trans to $\mathrm{CyO}$, namely $\mathrm{BicC}^{\gamma \mathrm{C} 33} / \mathrm{CyO}$ and $\mathrm{BicC}^{\mathrm{IIF3} 3} / \mathrm{CyO}$. BicC mutants were selected as the straight-winged progeny with genotypes $D f(2 L) R A 5 / B i c^{Y C 33}$ (hereby Bic $C^{\Delta / Y C 33}$ ) and $D f(2 L) R A 5 / B_{i c} C^{I I F 34}$, (hereby Bic $C^{\Delta / I F 34}$ ). Such BicC allelic combinations produce truncated proteins and sterile BicC flies [21]. The Bic ${ }^{\Delta / I F 34}$ genotype yields a more severe cystic phenotype than the $\mathrm{BicC}^{\Delta / Y C 33}$ combination and may be dominant negative [21]. Eclosed adult flies were collected every two days to generate 0-2-day old populations to be used in the assays. 


\subsection{Cystic Index}

The cystic analysis was performed as in [30], with the following modifications. The 0-2-day old BicC mutant females were housed in vials containing $2 \mathrm{~mL}$ cornmeal food (Jazzmix, Fisher Scientific) that were replaced every three days to ensure freshness. During daytime, flies were fed plain cornmeal food. In the evening, flies were transferred into identical vials to which equal volumes (50 $\mu \mathrm{L})$ of either vehicle (ethanol, control) or $150 \mu \mathrm{M}$ melatonin (resuspended in ethanol) were added and then incubated overnight. In the morning, flies were transferred to vials with plain cornmeal food. The timing of dissection of the Malpighian tubules for melatonin efficacy was determined empirically with ten female flies micro-dissected at $8,12,18$, and 25 days after treatment beginning and 18 days post-treatment was chosen for further analyses. This corresponds to fly populations of individuals aged 18-20 days. Larger 0-2-day old fly populations were then established and fed either melatonin or vehicle as above for 18 days, after which the Malpighian tubules were micro-dissected from 50 female flies in phosphate buffered saline (PBS). Cysts were counted separately for the anterior and posterior tubules, differentiating each tubular region (i.e., proximal, intermediate and terminal), due to their known physiological differences ([157]; reviewed in [27]). Wild-type tubules are elongated and regularly shaped, while BicC mutant tubules appear larger and deformed by cysts. Cysts were scored as any tubular deformation creating uni- or bi-lateral expansions or extra-branches as in [30]. To determine that flies ingested melatonin, green dye was added to the food and melatonin mixture. After three days, the dye can be visualized through the semi-transparent abdominal cuticle (Figure S1). Data were plotted using the Graphpad Prism 8.0 software (https://www.graphpad.com/scientific-software/prism/) as nested distributions and analyzed statistically. Unpaired t-tests were performed with both Excel and Graphpad Prism 8.0 and the Welch's correction added, because the populations may not have equal standard deviations. $p$ values of less than 0.05 were considered significant and indicative of cyst-reducing activity. The cystic index raw data can be found in Table S1.

\subsection{Microscopy}

Malpighian tubules from aged and treated flies as indicated were manually micro-dissected in $1 \times$ PBS, washed and equilibrated into a 3:1 1× PBS:glycerol solution as in [30] and photographed on a Leica MZ FLIII Fluorescence Stereomicroscope with Leica MZ series 10×/21B Widefield adjustable eyepieces equipped with a Canon DS126201 EOS 5D MARK II camera, using visible light. Canon raw files (CR2) were converted into TIF format using the Adobe Lightroom 3.2 software (Adobe Systems, San Jose, CA, USA).

Supplementary Materials: The following are available online, Figure S1: Melatonin feeding control, Table S1: Cystic index raw data.

Author Contributions: Conceptualization, C.M.-B., R.R., F.P., and C.G.; methodology, C.M.-B. and C.G.; formal analysis, C.M.-B. and C.G.; investigation, C.M.-B. and C.G.; resources, C.G.; data curation, C.M.-B.; writing - original draft preparation, C.M.-B. and C.G.; writing—review and editing, C.M.-B., R.R., F.P., and C.G.; supervision, C.G.; funding acquisition, R.R., F.P., and C.G. All authors have read and agreed to the published version of the manuscript.

Funding: This research was funded by a Mitacs Accelerate Grant IT10214 and a Concordia University CUPFA Professional Development Grant to C.G.

Acknowledgments: We wish to thank W.D. Lubell and M. Therrien for sharing resources (Université de Montréal); C. Charbonneau (imaging facility, IRIC Montreal) and C. Law (CMCI, Concordia University) for assistance with imaging and data analyses facilities. C.G. is a member of the Center of Excellence in Research on Orphan Diseases-Fondation Courtois.

Conflicts of Interest: R.R. is the Chief Executive Officer and F.P. is the Chief Scientific Officer of BH BioScience. C.M.-B. and C.G. report no conflict of interest. The funders had no role in the design of the study; in the collection, analyses, or interpretation of data; in the writing of the manuscript, or in the decision to publish the results. 


\section{References}

1. Bergmann, C.; Guay-Woodford, L.M.; Harris, P.C.; Horie, S.; Peters, D.J.M.; Torres, V.E. Polycystic kidney disease. Nat. Rev. Dis. Primers 2018, 4, 50. [CrossRef]

2. Rowe, I.; Chiaravalli, M.; Mannella, V.; Ulisse, V.; Quilici, G.; Pema, M.; Song, X.W.; Xu, H.; Mari, S.; Qian, F.; et al. Defective glucose metabolism in polycystic kidney disease identifies a new therapeutic strategy. Nat. Med. 2013, 19, 488-493. [CrossRef] [PubMed]

3. Grantham, J.J. Polycystic kidney disease: Neoplasia in disguise. Am. J. Kidney Dis. 1990, 15, 110-116. [CrossRef]

4. Harris, P.C.; Watson, M.L. Autosomal dominant polycystic kidney disease: Neoplasia in disguise? Nephrol. Dial. Transplant. 1997, 12, 1089-1090. [CrossRef] [PubMed]

5. Yamaguchi, T.; Pelling, J.C.; Ramaswamy, N.T.; Eppler, J.W.; Wallace, D.P.; Nagao, S.; Rome, L.A.; Sullivan, L.P.; Grantham, J.J. cAMP stimulates the in vitro proliferation of renal cyst epithelial cells by activating the extracellular signal-regulated kinase pathway. Kidney Int. 2000, 57, 1460-1471. [CrossRef] [PubMed]

6. Shillingford, J.M.; Murci, N.S.; Larson, C.H.; Low, S.H.; Hedgepeth, R.; Brown, N.; Flask, C.A.; Novick, A.C.; Goldfarb, D.A.; Kramer-Zucker, A.; et al. The mTOR pathway is regulated by polycystin-1, and its inhibition reverses renal cystogenesis in polycystic kidney disease. Proc. Natl. Acad. Sci. USA 2006, 103, 5466-5471. [CrossRef] [PubMed]

7. Wilson, S.J.; Amsler, K.; Hyink, D.P.; Li, X.; Lu, W.; Zhou, J.; Burrow, C.R.; Wilson, P.D. Inhibition of HER-2 (new/ErbB2) restores normal function and structure to polycystic kidney disease (PKD) epithelia. Biochim. Biophys. Acta 2006, 1762, 647-655. [CrossRef] [PubMed]

8. Sweeney, W.E.; von Vigier, R.O.; Frost, P.; Avner, E.D. Src inhibition ameliorates polycystic kidney disease. J. Am. Soc. Nephrol. 2008, 19, 1331-1341. [CrossRef]

9. Lancaster, M.A.; Louie, C.M.; Silhavy, J.L.; Sintasath, L.; DeCambre, M.; Nigam, S.K.; Willert, K.; Gleeson, J.G. Impaired Wnt- $\beta$-catenin signaling disrupts adult renal homeostasis and leads to cystic kidney ciliopathy. Nat. Med. 2009, 15, 1046-1054. [CrossRef]

10. Shillingford, J.M.; Piontek, K.B.; Germino, G.G.; Weimbs, T. Rapamycin ameliorates PKD resulting from conditional inactivation of Pkd1. J. Am. Soc. Nephrol. 2010, 21, 489-497. [CrossRef]

11. Varelas, X.; Miller, B.W.; Sopko, R.; Song, S.; Gregorieff, A.; Fellouse, F.A.; Sakuma, R.; Pawson, T.; Hunziker, W.; McNeill, H.; et al. The Hippo pathway regulates Wnt/ $\beta$-catenin signaling. Dev. Cell 2010, 18, 579-591. [CrossRef]

12. Yamaguchi, T.; Reif, G.A.; Calvet, J.P.; Wallace, D.P. Sorafenib inhibits cAMP-dependent ERK activation, cell proliferation, and in vitro cyst growth of human ADPKD cyst epithelial cells. Am. J. Physiol. Renal Phys. 2010, 299, F944-F951. [CrossRef] [PubMed]

13. Wilson, P.D. Apico-basal polarity in polycystic kidney disease epithelia. Biochim. Biophys. Acta 2011, 1812, 1239-1248. [CrossRef] [PubMed]

14. Fedeles, S.; Gallagher, A.R. Cell polarity and cystic kidney disease. Pediatr. Nephrol. 2013, 28, 1161-1172. [CrossRef] [PubMed]

15. Goggolidou, P. Wnt and planar cell polarity signaling in cystic renal disease. Organogenesis 2014, 10, 86-95. [CrossRef] [PubMed]

16. Seeger-Nukpezah, T.; Geynisman, D.M.; Nikonova, A.S.; Benzing, T.; Golemis, E.A. The hallmarks of cancer: Relevance to the pathogenesis of polycystic kidney disease. Nat. Rev. Nephrol. 2015, 11, 515-534. [CrossRef] [PubMed]

17. Bonnet, C.S.; Aldred, M.; von Ruhland, C.; Harris, R.; Sandford, R.; Cheadle, J.P. Defects in cell polarity underlie TSC and ADPKD-associated cystogenesis. Hum. Mol. Genet. 2009, 18, 2166-2176. [CrossRef]

18. Fischer, D.C.; Jacoby, U.; Pape, L.; Ward, C.J.; Kuwertz-Broeking, E.; Renken, C.; Nizze, H.; Querfeld, U.; Rudolph, B.; Mueller-Wiefel, D.E.; et al. Activation of the AKT/mTOR pathway in autosomal recessive polycystic kidney disease (ARPKD). Nephrol. Dial. Transplant. 2009, 24, 1819-1827. [CrossRef] [PubMed]

19. Hartman, T.R.; Liu, D.; Zilfou, J.T.; Robb, V.; Morrison, T.; Watnick, T.; Henske, E.P. The tuberous sclerosis proteins regulate formation of the primary cilium via a rapamycin-insensitive and polycystin 1-independent pathway. Hum. Mol. Genet. 2009, 18, 151-163. [CrossRef]

20. Ibraghimov-Beskrovnaya, O.; Natoli, T.A. mTOR signaling in polycystic kidney disease. Trends Mol. Med. 2011, 17, 625-633. [CrossRef] 
21. Gamberi, C.; Hipfner, D.R.; Trudel, M.; Lubell, W.D. Bicaudal C mutation causes myc and TOR pathway up-regulation and polycystic kidney disease-like phenotypes in Drosophila. PLoS Genet. 2017, 13, e1006694. [CrossRef] [PubMed]

22. Lanoix, J.; D'Agati, V.; Szabolcs, M.; Trudel, M. Dysregulation of cellular proliferation and apoptosis mediates human autosomal dominant polycystic kidney disease (ADPKD). Oncogene 1996, 13, 1153-1160. [PubMed]

23. Trudel, M. C-Myc signalling in the genetic mechanism of polycystic kidney disease. In Polycystic Kidney Disease; Li, X., Ed.; Codon Publications: Brisbane, Australia, 2015; pp. 231-257.

24. Happe, H.; Peters, J.D.M. Translational research in ADPKD: Lessons from animal models. Nat. Rev. Nephrol. 2014, 10, 587-601. [CrossRef] [PubMed]

25. Gamberi, C.; Lasko, P. The Bic-C family of developmental translational regulators. Int. J. Genom. 2012, 2012, 141386. [CrossRef] [PubMed]

26. Chien, S.; Reiter, L.T.; Bier, E.; Gribskov, M. Homophila: Human disease gene cognates in Drosophila. Nucleic Acids Res. 2002, 30, 149-151. [CrossRef]

27. Millet-Boureima, C.; Porras, J.M.; Gamberi, C. Modeling renal disease "on the fly". BioMed Res. Int. 2018, 2018, 5697436. [CrossRef]

28. Cohen, E.; Sawyer, J.K.; Peterson, N.G.; Dow, J.A.T.; Fox, D.T. Physiology, development, and disease modeling in the Drosophila excretory system. Genetics 2020, 214, 235-264. [CrossRef]

29. Wang, J.; Kean, L.; Yang, J.; Allan, A.K.; Davies, S.A.; Herzyk, P.; Dow, J.A.T. Function-informed transcriptome analysis of Drosophila renal tubule. Genome Biol. 2004, 5, R69. [CrossRef]

30. Millet-Boureima, C.; Chingle, R.; Lubell, W.D.; Gamberi, C. Cyst reduction in a polycystic kidney disease Drosophila model using Smac mimics. Biomedicines 2019, 7, 82. [CrossRef]

31. Millet-Boureima, C.; Selber-Hnatiw, S.; Gamberi, C. Drug discovery and chemical probing in Drosophila. Genome 2020, 999, 1-13. [CrossRef]

32. Fan, L.X.; Zhou, X.; Sweeney, W.E.; Wallace, D.P.; Avner, E.D.; Grantham, J.J.; Li, X. Smac-mimetic-induced epithelial cell death reduces the growth of renal cysts. J. Am. Soc. Nephrol. 2013, 24, 2010-2022. [CrossRef] [PubMed]

33. Torres, V.E.; Chapman, A.B.; Devuyst, O.; Gansevoort, R.T.; Grantham, J.J.; Higashihara, E.; Perrone, R.D.; Krasa, H.B.; Ouyang, J.; Czerwiec, F.S. Tolvaptan in patients with autosomal dominant polycystic kidney disease. N. Engl. J. Med. 2012, 367, 2407-2418. [CrossRef] [PubMed]

34. Sans-Atxer, L.; Joly, D. Tolvaptan in the treatment of autosomal dominant polycystic kidney disease: Patient selection and special considerations. Int. J. Nephrol. Renovasc. Dis. 2018, 11, 41-51. [CrossRef]

35. Chiaravalli, M.; Rowe, I.; Mannella, V.; Quilici, G.; Canu, T.; Bianchi, V.; Gurgone, A.; Antunes, S.; D’Adamo, P.; Esposito, A.; et al. 2-Deoxy-d-glucose ameliorates PKD progression. Am. J. Soc. Nephrol. 2016, 27, 1958-1969. [CrossRef]

36. Kipp, K.R.; Rezaei, M.; Lin, L.; Dewey, E.C.; Weimbs, T. A mild reduction of food intake slows disease progression in an orthologous mouse model of polycystic kidney disease. Am. J. Phys. Renal Phys. 2016, 310, F726-F731. [CrossRef] [PubMed]

37. Torres, J.A.; Kruger, S.L.; Broderick, C.; Amarlkhagva, T.; Agrawal, S.; Dodam, J.R.; Mrug, M.; Lyons, L.A.; Weimbs, T. Ketosis ameliorates renal cyst growth in polycystic kidney disease. Cell Metab. 2019, 30, 1007-1023. [CrossRef]

38. Hardeland, R.; Balzer, I.; Poeggeler, B.; Fuhrberg, B.; Una, H.; Behrmann, G.; Wolf, R.; Meyer, T.J.; Reiter, R.J. On the primary functions of melatonin in evolution: Mediation of photoperiodic signals in a unicell, photooxidation, and scavenging of free radicals. J. Pineal Res. 1995, 18, 104-111. [CrossRef]

39. Venegas, C.; Garcia, J.A.; Escames, G.; Ortiz, F.; Lopez, A.; Doerrier, C.; Garcia-Corzo, L.; Lopez, L.C.; Reiter, R.J.; Acuna-Castroviejo, D. Extrapineal melatonin: Analysis of its subcellular distribution and daily fluctuations. J. Pineal Res. 2012, 52, 217-227. [CrossRef]

40. Slominski, A.; Tobin, D.J.; Zmijewski, M.A.; Wortsman, J.; Paus, R. Melatonin in the skin: Synthesis, metabolism and functions. Trends Endocrinol. Metab. 2008, 19, 17-24. [CrossRef]

41. Bubenik, G.A. Localization of melatonin in the digestive tract of the rat. Effect of maturation, diurnal variation, melatonin treatment and pinealectomy. Horm. Res. 1980, 12, 313-323. [CrossRef]

42. Lardone, P.J.; Guerrero, J.M.; Fernandez-Santos, J.M.; Rubio, A.; Martin-Lacave, I.; Carrillo-Vico, A. Melatonin synthesized by $\mathrm{T}$ lymphocytes as a ligand of the retinoic acid-related orphan receptor. J. Pineal Res. 2011, 51, 454-462. [CrossRef] 
43. Suofu, Y.; Li, W.; Jean-Alphonse, F.G.; Jia, J.; Khattar, N.K.; Li, J.; Baranov, S.V.; Leronni, D.; Mihalik, A.C.; $\mathrm{He}$, Y.; et al. Dual role of mitochondria in producing melatonin and driving GPCR signaling to block cytochrome c release. Proc. Natl. Acad. Sci. USA 2017, 114, E7997-E8006. [CrossRef]

44. Cipolla-Neto, J.; Gaspar do Amaral, F. Melatonin as a hormone: New physiological and clinical insights. Endocr. Rev. 2018, 39, 990-1028. [CrossRef]

45. Reiter, R.J. Pineal melatonin: Cell biology of its synthesis and of its physiological interactions. Endocr. Rev. 1991, 12, 151-180. [CrossRef]

46. Reiter, R.J.; Tan, D.X.; Fuentes-Broto, L. Melatonin: A multitasking molecule. Prog. Brain Res. 2010, 181, $127-151$.

47. Slominski, R.M.; Reiter, R.J.; Schlabritz-Loutsevitch, N.; Ostrom, R.S.; Slominski, A.T. Melatonin membrane receptors in peripheral tissues: Distribution and functions. Mol. Cell. Endocrinol. 2012, 351, 152-166. [CrossRef]

48. Jenwitheesuk, A.; Nopparat, C.; Mukda, S.; Wongshitrat, P.; Govitrapong, P. Melatonin regulates aging and neurodegeneration through energy metabolism, epigenetics, autophagy and circadian rhythm pathways. Int. J. Mol. Sci. 2014, 15, 16848-16884. [CrossRef]

49. Su, S.; Hsieh, M.J.; Yang, W.E.; Chung, W.H.; Reiter, R.J.; Yang, S.F. Cancer metastasis: Mechanisms of inhibition by melatonin. J. Pineal Res. 2017, 62, e12370. [CrossRef]

50. Bhattacharya, S.; Patel, K.K.; Dehari, D.; Agrawal, A.K.; Singh, S. Melatonin and its ubiquitous anticancer effects. Mol. Cell. Biochem. 2019, 462, 133-155. [CrossRef]

51. Sainz, R.M.; Mayo, J.C.; Rodriguez, C.; Tan, D.X.; Lopez-Burillo, S.; Reiter, R.J. Melatonin and cell death: Differential actions on apoptosis in normal and cancer cells. Cell. Mol. Life Sci. 2003, 60, 1407-1426. [CrossRef]

52. Yousaf, F.; Seet, E.; Venkatraghavan, L.; Abrishami, A.; Chung, F. Efficacy and safety of melatonin as an anxiolytic and analgesic in the perioperative period: A qualitative systemic review of randomized trials. Anesthesiology 2010, 113, 968-976. [CrossRef]

53. Pourhanifeh, M.H.; Sharifi, M.; Reiter, R.J.; Davoodabadi, A.; Asemi, Z. Melatonin and non-small cell lung cancer: New insights into signaling pathways. Cancer Cell Int. 2019, 19, 131. [CrossRef]

54. Mantovani, M.; Kaster, M.P.; Pertile, R.; Calixto, J.B.; Rodrigues, A.L.S.; Santos, A.R.S. Mechanisms involved in the antinociception caused by melatonin in mice. J. Pineal Res. 2006, 41, 382-389. [CrossRef]

55. Dilman, V.M.; Anisimov, V.N.; Ostroumova, M.N.; Khavinson, V.K.; Morozov, V.G. Increase in lifespan of rats following polypeptide pineal extract treatment. Exp. Pathol. (Jena) 1979, 17, 539-545. [CrossRef]

56. Anisimov, V.N.; Mylnikov, S.V.; Oparina, T.I.; Khavinson, V.K. Effect of melatonin and pineal peptide preparation epithalamin on life span and free radical oxidation in Drosophila melanogaster. Mech. Ageing Dev. 1997, 97, 81-91. [CrossRef]

57. Anisimov, V.N.; Zavarzina, N.Y.; Zabezhinski, M.A.; Popovich, I.G.; Zimina, O.A.; Shtylick, A.V.; Arutjunyan, A.V.; Oparina, T.I.; Prokopenko, V.M.; Mikhalski, A.I.; et al. Melatonin increases both life span and tumor incidence in female CBA mice. J. Gerontol. A Biol. Sci. Med. Sci. 2001, 56, B311-B323. [CrossRef]

58. Reiter, R.J. Mechanisms of cancer inhibition by melatonin. J. Pineal Res. 2004, 37, 213-214. [CrossRef]

59. Anisimov, V.N.; Popovich, I.G.; Zabezhinski, M.A.; Anisimov, S.V.; Vesnushkin, G.M.; Vinogradova, I.A. Melatonin as antioxidant, geroprotector and anticarcinogen. Biochim. Biophys. Acta 2006, 1757, 573-589. [CrossRef]

60. Li, Y.; Li, S.; Zhou, Y.; Meng, X.; Zhang, J.J.; Xu, D.P.; Li, H.B. Melatonin for the prevention and treatment of cancer. Oncotarget 2017, 8, 39896-39921. [CrossRef]

61. Reiter, R.J.; Rosales-Corral, S.A.; Tan, D.X.; Acuna-Castroviejo, D.; Qin, L.; Yang, S.F.; Xu, K. Melatonin, a full service and anti-cancer agent: Inhibition of initiation, progression and metastasis. Int. J. Mol. Sci. 2017, 18, 843. [CrossRef]

62. Aubert, C.H.; Janiaud, P.; Lecalvez, J. Effect of pinealectomy and melatonin on mammary tumor growth in Sprague-Dawley rats under different conditions of lighting. J. Neural Transm. 1980, 47, 121-130. [CrossRef]

63. Tamarkin, L.; Cohen, M.; Roselle, D.; Reichert, C.; Lippman, M.; Chabner, B. Melatonin inhibition and pinealectomy enhancement of 7, 12-dimethylbenz (a) anthracene-induced mammary tumors in the rat. Am. Assoc. Cancer Res. 1981, 41, 4432-4436.

64. Mediavilla, M.D.; Cos, S.; Sanchez-Barcelo, E.J. Melatonin increases p53 and p21 WAF1 expression in MCF-7 human breast cancer cells in vitro. Life Sci. 1999, 65, 415-420. [CrossRef]

65. Cos, S.; Mediavilla, M.D.; Fernandez, R.; Gonzalez-Lamuno, D.; Sanchez-Barcelo, E.J. Does melatonin induce apoptosis in MCF-7 human breast cancer cells in vitro? J. Pineal Res. 2002, 32, 90-96. [CrossRef]

66. Cos, S.; Martinez-Campa, C.; Mediavilla, M.D.; Sanchez-Barcelo, E.J. Melatonin modulates aromatase activity in MCF-7 human breast cancer cells. J. Pineal Res. 2005, 38, 136-142. [CrossRef] 
67. Martinez-Campa, C.; Alonso-Gonzalez, C.; Mediavilla, M.D.; Cos, S.; Gonzalez, A.; Ramos, S.; Sanchez-Barcelo, E.J. Melatonin inhibits both Er $\alpha$ activation and breast cancer cell proliferation induced by a metalloestrogen, cadmium. J. Pineal Res. 2006, 40, 291-296. [CrossRef]

68. Hill, S.M.; Belancio, V.P.; Dauchy, R.T.; Xiang, S.; Brimer, S.; Mao, L.; Hauch, A.; Lundberg, P.W.; Summers, W.; Yuan, L.; et al. Melatonin: An inhibitor of breast cancer. Endocr. Relat. Cancer 2015, 22, R183-R204. [CrossRef]

69. Fischer, T.W.; Zmijewski, M.A.; Zbytek, B.; Sweatman, T.W.; Slominski, R.M.; Wortsman, J.; Slominski, A. Oncostatic effects of the indole melatonin and expression of its cytosolic and nuclear receptors in cultured human melanoma cell lines. Int. J. Oncol. 2006, 29, 665-672. [CrossRef]

70. Cabrera, J.; Negrin, G.; Estevez, F.; Loro, J.; Reiter, R.J.; Quintana, J. Melatonin decreases cell proliferation and induces melanogenesis in human melanoma SK-MEL-1 cells. J. Pineal Res. 2010, 49, 45-54. [CrossRef]

71. Choi, S.I.; Kim, K.S.; Oh, J.Y.; Jin, J.Y.; Lee, G.H.; Kim, E.K. Melatonin induces autophagy via an mTOR-dependent pathway and enhances clearance of mutant-TGFBlp. J. Pineal Res. 2013, 54, 361-372. [CrossRef]

72. Ding, K.; Wang, H.; Xu, J.; Lu, X.; Zhang, L.; Zhu, L. Melatonin reduced microglial activation and alleviated neuroinflammation induced neuron degeneration in experimental traumatic brain injury: Possible involvement of mTOR pathway. Neurochem. Int. 2014, 76, 23-31. [CrossRef]

73. Kang, J.W.; Cho, H.I.; Lee, S.M. Melatonin inhibits mTOR-dependent autophagy during liver ischemia/reperfusion. Cell. Physiol. Biochem. 2014, 33, 23-36. [CrossRef] [PubMed]

74. Kim, H.S.; Kim, T.J.; Yoo, Y.M. Melatonin combined with endoplasmic reticulum stress induces cell death via the PI3K/Akt/mTOR pathway in B16F10 melanoma cells. PLoS ONE 2014, 9, e92627. [CrossRef] [PubMed]

75. Li, W.; Fan, M.; Chen, Y.; Zhao, Q.; Song, C.; Yan, Y.; Jin, Y.; Huang, Z.; Lin, C.; Wu, J. Melatonin induces cell apoptosis and AGS cells through the activation of JNK and P38 MAPK and the suppression of nuclear factor-kappa B: A novel therapeutic implication for gastric cancer. Cell. Physiol. Biochem. 2015, 37, $2323-2338$. [CrossRef]

76. Behram Kandemir, Y.; Aydin, C.; Gorgisen, G. The effects of melatonin on oxidative stress and prevention of primordial follicle loss via activation of mTOR pathway in the rat ovary. Cell. Mol. Biol. (Noisy-Le-Grand) 2017, 63, 100-106. [CrossRef]

77. Tan, D.X.; Chen, L.D.; Peoggeler, B.; Manchester, L.C.; Reiter, R.J. Melatonin: A potent, endogenous hydroxyl radical scavenger. Endocr. J. 1993, 1, 57-60.

78. Reiter, R.J. Oxidative damage to nuclear DNA: Amelioration by melatonin. Neuro. Endocrinol. Lett. 1999, $20,145-150$.

79. Karbownik, M.; Tan, D.X.; Reiter, R.J. Melatonin reduces the oxidation of nuclear DNA and membrane lipids induced by the carcinogen $\delta$-aminolevulinic acid. Int. J. Cancer 2000, 88, 7-11. [CrossRef]

80. Khavinson, V.K.; Izmaylov, D.M.; Obukhova, L.K.; Malinin, V.V. Effect of epitalon on the lifespan increase in Drosophila melanogaster. Mech. Ageing Dev. 2000, 120, 141-149. [CrossRef]

81. Qi, W.; Reiter, R.J.; Tan, D.X.; Manchester, L.C.; Siu, A.W.; Garcia, J.J. Increased levels of oxidatively damaged DNA induced by chromium (III) and $\mathrm{H}_{2} \mathrm{O}_{2}$ : Protection by melatonin and related molecules. J. Pineal Res. 2000, 29, 54-61. [CrossRef] [PubMed]

82. Reiter, R.J. Melatonin: Lowering the high price of free radicals. Newws Physiol. Sci. 2000, 15, 246-250. [CrossRef]

83. Karbownik, M.; Lewinski, A.; Reiter, R.J. Anticarcinogenic actions of melatonin which involve antioxidative processes: Comparison with other antioxidants. Int. J. Biochem. Cell Biol. 2001, 33, 735-753. [CrossRef]

84. Karbownik, M.; Reiter, R.J. Melatonin protects against oxidative stress caused by d-aminolevulinic acid: Implications for cancer. Cancer Investig. 2002, 20, 276-286. [CrossRef]

85. Yang, Q.H.; Xu, J.N.; Xu, R.K.; Pang, S.F. Inhibitory effects of melatonin on the growth of pituitary prolactin-secreting tumor in rats. J. Pineal Res. 2006, 40, 230-235. [CrossRef]

86. Rossi, S.P.; Windschuetti, S.; Matzkin, M.E.; Terradas, C.; Ponzio, R.; Puigdomenech, E.; Levalle, O.; Calandra, R.S.; Mayerhofer, A.; Frungieri, M.B. Melatonin in testes of infertile men: Evidence for anti-proliferative and anti-oxidant effects on local macrophage and mast cell populations. Andrology 2014, 2, 436-449. [CrossRef]

87. Zhang, H.; Zhang, Y. Melatonin: A well-documented antioxidant with conditional pro-oxidant actions. J. Pineal Res. 2014, 57, 131-146. [CrossRef]

88. Burattini, S.; Battistelli, M.; Codenotti, S.; Falcieri, E.; Fanzani, A.; Salucci, S. Melatonin action in tumor skeletal muscle cells: An ultrastructural study. Acta Histochem. 2016, 118, 278-285. [CrossRef]

89. Galadari, S.; Rahman, A.; Pallichankandy, S.; Thayyullathil, F. Reactive oxygen species and cancer paradox: To promote or suppress? Free Radic. Biol. Med. 2017, 104, 144-164. [CrossRef] 
90. Galano, A.; Reiter, R.J. Melatonin and its metabolites vs oxidative stress: From individual actions to collective protection. J. Pineal Res. 2018, 65, e12514. [CrossRef]

91. Longaretti, L.M.; Luciano, J.A.; Strapazzon, G.; Pereira, M.; Damiani, A.P.; Rohr, P.; Rigo, F.K.; Alves de Oliveira, C.; Steiner, B.T.; Vilela, T.C.; et al. Anti-genotoxic and anti-mutagenic effects of melatonin supplementation in a mouse model of melanoma. Drug Chem. Toxicol. 2020, 1-8. [CrossRef]

92. Leon-Blanco, M.M.; Guerrero, J.M.; Reiter, R.J.; Calvo, J.R.; Pozo, D. Melatonin inhibits telomerase activity in the MCF-7 tumor cell line both in vivo and in vitro. J. Pineal Res. 2003, 35, 204-211. [CrossRef] [PubMed]

93. Leja-Szpak, A.; Jaworek, J.; Pierzchalski, P.; Reiter, R.J. Melatonin induces pro-apoptotic signaling pathway in human pancreatic carcinoma cells (PANC-1). J. Pineal Res. 2010, 49, 248-255. [CrossRef] [PubMed]

94. Bizzarri, M.; Proietti, S.; Cucina, A.; Reiter, R.J. Molecular mechanisms of the pro-apoptotic actions of melatonin in cancer: A review. Expert Opin. Ther. Targets 2013, 17, 1483-1496. [CrossRef] [PubMed]

95. Srinivasan, V.; Spence, D.W.; Pandi-Perumal, S.R.; Trakht, I.; Cardinalli, D.P. Therapeutic actions of melatonin in cancer: Possible mechanisms. Integr. Cancer Ther. 2008, 7, 189-203. [CrossRef]

96. Lv, D.; Cui, P.L.; Yao, S.W.; Xu, Y.Q.; Yang, Z.X. Melatonin inhibits the expression of vascular endothelial growth factor in pancreatic cancer cells. Chin. J. Cancer Res. 2012, 24, 310-316. [CrossRef]

97. Alvarez-Garcia, V.; Gonzalez, A.; Alonso-Gonzalez, C.; Martinez-Campa, C.; Cos, S. Antiangiogenic effects of melatonin in endothelial cell cultures. Microvasc. Res. 2013, 87, 25-33. [CrossRef]

98. Ma, Q.; Reiter, R.J.; Chen, Y. Role of melatonin in controlling angiogenesis under physiological and pathological conditions. Angiogenesis 2020, 23, 91-104. [CrossRef]

99. Parker, M.I.; Nikonova, A.S.; Sun, D.; Golemis, E.A. Proliferative signaling by ERBB proteins and RAF/MEK/ERK effectors in polycystic kidney disease. Cell. Signal. 2020, 67, 109497. [CrossRef]

100. Maser, R.L.; Vassmer, D.; Magenheimer, B.S.; Clavet, J.P. Oxidant stress and reduced antioxidant enzyme protection in polycystic kidney disease. J. Am. Soc. Nephrol. 2002, 13, 991-999.

101. Menon, V.; Rudym, D.; Chandra, P.; Miskulin, D.; Perrone, R.; Sarnak, M. Inflammation, oxidative stress, and insulin resistance in polycystic kidney disease. Clin. J. Am. Soc. Nephrol. 2011, 6, 7-13. [CrossRef]

102. Klawitter, J.; Reed-Gitomer, B.Y.; McFann, K.; Pennington, A.; Klawitter, J.; Abebe, K.Z.; Klepacki, J.; Cadnapaphornchai, M.A.; Brosnahan, G.; Chonchoi, M.; et al. Endothelial dysfunction and oxidative stress in polycystic kidney disease. Am. J. Physiol. Renal Physiol. 2014, 307, F1198-F1206. [CrossRef] [PubMed]

103. Ferrandon, D.; Imler, J.L.; Hetru, C.; Hoffmann, J.A. The Drosophila systemic immune response: Sensing and signaling during bacterial and fungal infections. Nat. Rev. Immunol. 2007, 7, 862-874. [CrossRef] [PubMed]

104. Buchon, N.; Broderick, N.A.; Chakrabarti, S.; Lemaitre, B. Invasive and indigenous microbiota impact intestinal stem cell activity through multiple pathways in Drosophila. Genes Dev. 2009, 23, 2333-2344. [CrossRef] [PubMed]

105. Nguyen, T.; Nioi, P.; Pickett, C.B. The Nrf2-antioxidant response element signaling pathway and its activation by oxidative stress. J. Biol. Chem. 2009, 284, 13291-13295. [CrossRef] [PubMed]

106. Wu, S.C.; Liao, C.W.; Pan, R.L.; Juang, J.L. Infection-induced intestinal oxidative stress triggers organ-to-organ immunological communication in Drosophila. Cell Host Microbe 2012, 11, 410-417. [CrossRef] [PubMed]

107. Jahnke, G.; Marr, M.; Myers, C.; Wilson, R.; Travlos, G.; Price, C. Maternal and developmental toxicity evaluation of melatonin administered orally to pregnant Sprague-Dawley rats. Toxicol. Sci. 1999, 50, 271-279. [CrossRef]

108. Andersen, L.P.H.; Gogenur, I.; Rosenberg, J.; Reiter, R.J. The safety of melatonin in humans. Clin. Drug Investig. 2016, 36, 169-175. [CrossRef] [PubMed]

109. Reiter, R.J.; Mayo, J.C.; Tan, D.X.; Sainz, R.M.; Alatorre-Jimenez, M.; Qin, L. Melatonin as an antioxidant: Under promises but over delivers. J. Pineal Res. 2016, 61, 253-278. [CrossRef]

110. Saffman, E.E.; Styhler, S.; Rother, K.; Li, W.; Richard, S.; Lasko, P. Premature translation of oskar in oocytes lacking the RNA-binding protein bicaudal-C. Mol. Cell. Biol. 1998, 18, 4855-4862. [CrossRef]

111. Quiroz, Y.; Ferrebuz, A.; Romero, F.; Vaziri, N.D.; Rodriguez-Iturbe, B. Melatonin ameliorates oxidative stress, inflammation, proteinuria, and progression of renal damage in rats with renal mass reduction. Am. J. Physiol. Renal Physiol. 2008, 294, F336-F344. [CrossRef]

112. Koch, B.C.P.; van der Putten, K.; Van Someren, E.J.W.; Wielders, J.P.M.; Ter Wee, P.M.; Nagtegaal, J.E.; Gaillard, C.A.J.M. Impairment of endogenous melatonin rhythm is related to the degree of chronic kidney disease (CREAM study). Nephrol. Dial. Transplant. 2010, 25, 513-519. [CrossRef] [PubMed] 
113. Russcher, M.; Koch, B.; Nagtegaal, E.; van der Putten, K.; ter Wee, P.; Gaillard, C. The role of melatonin treatment in chronic kidney disease. Front. Biosci. 2012, 17, 2644-2656. [CrossRef] [PubMed]

114. Ohashi, N.; Ishigaki, S.; Isobe, S. The pivotal role of melatonin in ameliorating chronic kidney disease by suppression of the renin-angiotensin system in the kidney. Hypertens. Res. 2019, 42, 761-768. [CrossRef] [PubMed]

115. Oktem, F.; Ozguner, F.; Mollaoglu, H.; Koyu, A.; Uz, E. Oxidative damage in the kidney induced by 900-MHz-emitted mobile phone: Protection by melatonin. Arc. Med. Res. 2005, 36, 350-355. [CrossRef]

116. Adewole, S.O.; Salako, A.A.; Doherty, O.W.; Naicker, T. Effect of melatonin on carbon tetrachloride-induced kidney injury in Wistar rats. Afr. J. Biomed. Res. 2007, 10, 153-164. [CrossRef]

117. Mahieu, S.; del Carmen Contini, M.; Gonzalez, M.; Millen, N. Melatonin reduces oxidative damage induced by aluminium in rat kidney. Toxicol. Lett. 2009, 190, 9-15. [CrossRef]

118. Kobori, H.; Katsurada, A.; Ozawa, Y.; Satou, R.; Miyata, K.; Hase, N.; Suzaki, Y.; Shoji, T. Enhanced intrarenal oxidative stress and angiotensinogen in IgA nephropathy patients. Biochem. Biophys. Res. Commun. 2007, 358, 156-163.

119. Kamiyama, M.; Urushihara, M.; Morikawa, T.; Konishi, Y.; Imanishi, M.; Nishiyama, A.; Kobori, H. Oxidative stress/angiotensinogen/renin-angiotensin system axis in patients with diabetic nephropathy. Int. J. Mol. Sci. 2013, 14, 23045-23062. [CrossRef]

120. Andries, A.; Daenen, K.; Jouret, F.; Bammens, B.; Mekahli, D.; Van Schepdael, A. Oxidative stress in autosomal dominant polycystic kidney disease: Player and/or early predictor for disease progression? Pediatr. Nephrol. 2019, 34, 993-1008. [CrossRef]

121. Toung, Y.P.; Hsieh, T.S.; Tu, C.P. The glutathione S-transferase D genes. A divergently organized, intronless gene family in Drosophila melanogaster. J. Biol. Chem. 1993, 268, 9737-9746.

122. Kabil, H.; Partridge, L.; Harshman, L.G. Superoxide dismutase activities in long-lived Drosophila melanogaster females: Chico1 genotypes and dietary dilution. Biogenrontology 2007, 8, 201-208. [CrossRef] [PubMed]

123. Jung, I.; Kim, T.Y.; Kim-Ha, J. Identification of Drosophila SOD3 and its protective role against phototoxic damage to cells. FEBS Lett. 2011, 585, 1973-1978. [CrossRef] [PubMed]

124. Verhagen, A.M.; Vaux, D.L. Cell death regulation by the mammalian IAP antagonist Diablo/Smac. Apoptosis 2002, 7, 163-166. [CrossRef]

125. Lalaoui, N.; Vaux, D.L. Recent advances in understanding inhibitor of apoptosis proteins. F1000Research 2018, 7, F1000 Faculty Rev-1889. [CrossRef]

126. Cong, H.; Xu, L.; Wu, Y.; Qu, Z.; Bian, T.; Zhang, W.; Xing, C.; Zhuang, C. Inhibitor of apoptosis protein (IAP) antagonists in anticancer agent discovery: Current status and perspectives. J. Med. Chem. 2019, 62, 5750-5772. [CrossRef] [PubMed]

127. Li, X.; Magenheimer, B.S.; Xia, S.; Johnson, T.; Wallace, D.P.; Calvet, J.P.; Li, R. A tumor necrosis factor-alpha-mediated pathway promoting autosomal dominant polycystic kidney disease. Nat. Med. 2008, 14, 863-868. [CrossRef]

128. Igaki, T.; Kanda, H.; Yamamoto-Goto, Y.; Kanuka, H.; Kuranaga, E.; Aigaki, T.; Miura, M. Eiger, a TNF superfamily ligand that triggers the Drosophila JNK pathway. EMBO J. 2002, 21, 3009-3018. [CrossRef]

129. Kanda, H.; Igaki, T.; Kanuka, H.; Yagi, T.; Miura, M. Wengen, a member of the Drosophila tumor necrosis factor receptor superfamily, is required for Eiger signaling. J. Biol. Chem. 2002, 277, 28372-28375. [CrossRef] [PubMed]

130. Moreno, E.; Yan, M.; Basler, K. Evolution of TNF signaling mechanisms: JNK-dependent apoptosis triggered by Eiger, the Drosophila homolog of the TNF superfamily. Curr. Biol. 2002, 12, 1263-1268. [CrossRef]

131. Andersen, D.S.; Colombani, J.; Palmerini, V.; Chakrabandhu, K.; Boone, E.; Rothlisberger, M.; Toggweiler, J.; Basler, J.; Mapelli, M.; Hueber, A.O.; et al. The Drosophila TNF receptor Grindelwald couples loss of cell polarity and neoplastic growth. Nature 2015, 522, 482-486. [CrossRef]

132. Sasaki, M.; Jordan, P.; Joh, T.; Itoh, M.; Jenkins, M.; Pavlick, K.; Minagar, A.; Alexander, S.J. Melatonin reduces TNF- $\alpha$ induced expression of MAdCAM-1 via inhibition of NF-kB. BMC Gastroenterol. 2002, 2, 9. [CrossRef] [PubMed]

133. Xu, X.; Wang, G.; Ai, L.; Shi, J.; Zhang, J.; Chen, Y.X. Melatonin suppresses TLR9-triggered proinflammatory cytokine production in macrophages by inhibiting ERK1/2 and AKT activation. Sci. Rep. 2018, 8, 15579. [CrossRef] [PubMed] 
134. Huang, C.C.; Chiou, C.H.; Liu, S.C.; Hu, S.L.; Su, C.M.; Tsai, C.H.; Tang, C.H. Melatonin attenuates TNF- $\alpha$ and IL- $1 \beta$ expression in synovial fibroblasts and diminishes cartilage degradation: Implications for the treatment of rheumatoid arthritis. J. Pineal Res. 2019, 66, e12560. [CrossRef] [PubMed]

135. Saberi, K.; Pasbakhsh, P.; Omidi, A.; Borhani-Haghighi, M.; Nekoonam, S.; Omidi, N.; Ghasemi, S.; Kashani, I.R. Melatonin preconditioning of bone-marrow derived mesenchymal stem cells promotes their engraftment and improves renal regeneration in a rat model of chronic kidney disease. J. Mol. Hist. 2019, 50, 129-140. [CrossRef]

136. Hill, S.M.; Blask, D.E. Effects of the pineal hormone melatonin on the proliferation and morphological characteristics of human breast cancer cells (MCF-7) in culture. Cancer Res. 1988, 48, 6121-6126.

137. Cos, S.; Fernandez, R.; Guezmes, A.; Sanchez-Barcelo, E.J. Influence of melatonin on invasive and metastatic properties of MCF-7 human breast cancer cells. Cancer Res. 1998, 58, 4383-4390.

138. Papazisis, K.T.; Kouretas, D.; Geromichalos, G.D.; Sivridis, E.; Tsekreli, O.K.; Dimitriadis, K.A.; Kortsaris, A.H. Effects of melatonin on proliferation of cancer cell lines. J. Pineal Res. 1998, 25, 211-218. [CrossRef]

139. Petranka, J.; Baldwin, W.; Biermann, J.; Jayadev, S.; Barrett, J.C.; Murphy, E. The oncostatic action of melatonin in an ovarian carcinoma cell line. J. Pineal Res. 1999, 26, 129-136. [CrossRef]

140. Farriol, M.; Venereo, Y.; Orta, X.; Castellanos, J.M.; Segovia-Silvestre, T. In vitro effects of melatonin on cell proliferation in a colon adenocarcinoma line. J. Appl. Toxicol. 2000, 20, 21-24. [CrossRef]

141. Marelli, M.M.; Limonta, P.; Maggi, R.; Motta, M.; Moretti, R.M. Growth-inhibitory activity of melatonin on human androgen-independent DU 145 prostate cancer cells. Prostate 2000, 45, 238-244. [CrossRef]

142. Zhang, W.; Liu, H.T. MAPK signal pathways in the regulation of cell proliferation in mammalian cells. Cell Res. 2002, 12, 9-18. [CrossRef]

143. Cui, P.; Yu, M.; Luo, Z.; Dai, M.; Han, J.; Xiu, R.; Yang, Z. Intracellular signaling pathways involved in cell growth inhibition of human umbilical vein endothelial cells by melatonin. J. Pineal Res. 2008, 44, 107-114. [CrossRef]

144. Smith, E. Health and disease, as influenced by the daily, seasonal, and other cyclical changes in the human system. In The Edinburgh Medical and Surgical Journal; Walton and Maberly: London, UK, 1861; pp. 1128-1130.

145. Mills, J.N.; Stanbury, S.W. Persistent 24-hour renal excretory rhythm on a 12 -hour cycle of activity. J. Physiol. 1952, 117, 22-37. [PubMed]

146. Wu, T.; Ni, Y.; Dong, Y.; Xu, J.; Song, X.; Kato, H.; Fu, Z. Regulation of circadian gene expression in the kidney by light and food cues in rats. Am. J. Physiol. Regul. Integr. Comp. Physiol. 2010, 298, R635-R641. [CrossRef] [PubMed]

147. Hanly, P. Sleep disorders and end-stage renal disease. Curr. Opin. Pulm. Med. 2008, 14, 543-550. [CrossRef] [PubMed]

148. De Santo, R.M.; Perna, A.; Di Iorio, B.R.; Cirillo, M. Sleep disorders in kidney disease. Minerva Urol. Nefrol. 2010, 62, 111-128. [PubMed]

149. Pierratos, A.; Hanly, P.J. Sleep disorders over the full range of chronic kidney disease. Blood Purif. 2011, 31 , 146-150. [CrossRef]

150. Ezzat, H.; Mohab, A. Prevalence of sleep disorders among ESRD patients. Ren. Fail. 2015, 37, $1013-1019$. [CrossRef]

151. Lin, H.Y.H.; Hung, C.C.; Chang, Y.H.; Lin, M.Y.; Yang, M.Y.; Liang, S.S.; Liu, W.; Chen, H.C.; Hwang, S.J. Nonapnea sleep disorders in patients younger than 65 years are significantly associated with CKD: A nationwide population-based study. PLoS ONE 2015, 10, e0140401. [CrossRef]

152. Maung, S.C.; El Sara, A.; Chapman, C.; Cohen, D.; Cukor, D. Sleep disorders and chronic kidney disease. World J. Nephrol. 2016, 5, 224-232. [CrossRef]

153. Nigam, G.; Camacho, M.; Chang, E.T.; Riaz, M. Exploring sleep disorders in patients with chronic kidney disease. Nat. Sci. Sleep 2018, 10, 35-43. [CrossRef] [PubMed]

154. Edalat-Nejad, M.; Haqhverdi, F.; Hossein-Tabar, T.; Ahmadian, M. Melatonin improves sleep quality in hemodialysis patients. Indian J. Nephrol. 2013, 23, 264-269. [CrossRef] [PubMed]

155. Chen, H.H.; Lin, K.C.; Wallace, C.G.; Chen, Y.T.; Yang, C.C.; Leu, S.; Chen, Y.C.; Sun, C.K.; Tsai, T.H.; Chen, Y.L.; et al. Additional benefit of combined therapy with melatonin and apoptotic adipose-derived mesenchymal stem cell against sepsis-induced kidney injury. J. Pineal Res. 2014, 57, 16-32. [CrossRef] [PubMed]

156. Zhao, L.; Hu, C.; Zhang, P.; Jiang, H.; Chen, J. Melatonin preconditioning is an effective strategy for mesenchymal stem cell-based therapy for kidney disease. J. Cell. Mol. Med. 2019, 24, 25-33. [CrossRef] 
157. Sozen, M.A.; Armstrong, J.D.; Yang, M.; Kaiser, K.; Dow, J.A.T. Functional domains are specified to single-cell resolution in a Drosophila epithelium. Proc. Natl. Acad. Sci. USA 1997, 94, 5207-5212. [CrossRef]

158. Wilson, S.T.; Blask, D.E.; Lemus-Wilson, A.M. Melatonin augments the sensitivity of MCF-7 human breast cancer cells to tamoxifen in vitro. J. Clin. Endocrinol. Metab. 1992, 75, 669-670.

159. Reiter, R.J.; Tan, D.X.; Sainz, R.M.; Mayo, J.C.; Lopez-Burillo, S. Melatonin: Reducing the toxicity and increasing the efficacy of drugs. J. Pharm. Pharmacol. 2002, 54, 1299-1321. [CrossRef]

160. Lissoni, P.; Brivio, F.; Fumagalli, L.; Messina, G.; Vigore, L.; Parolini, D.; Colciago, M.; Rovelli, F. Neuroimmunomodulation in medical oncology: Application of psychoneuroimmunology with subcutaneous low-dose IL-2 and the pineal hormone melatonin in patients with untreatable metastatic solid tumors. Anticancer Res. 2008, 28, 1377-1381.

161. Ruiz-Rabelo, J.; Vazquez, R.; Arjona, A.; Perea, D.; Montilla, P.; Tunez, I.; Muntane, J.; Padillo, J. Improvement of capecitabine antitumoral activity by melatonin in pancreatic cancer. Pancreas 2011, 40, 410-414. [CrossRef]

162. Kim, J.H.; Jeong, S.J.; Kim, B.; Yun, S.M.; Choi, D.Y.; Kim, S.H. Melatonin synergistically enhances cisplatin-induced apoptosis via the dephosphorylation of ERK/p90 ribosomal S6 kinase/heat shock protein 27 in SK-OV-3 cells. J. Pineal Res. 2012, 52, 244-252. [CrossRef]

163. Margheri, M.; Pacini, N.; Tani, A.; Nosi, D.; Squecco, R.; Dama, A.; Masala, E.; Francini, F.; Zecchi-Orlandini, S.; Formigli, L. Combined effects of melatonin and all-trans retinoic acid and somatostatin on breast cancer cell proliferation and death: Molecular basis for the anticancer effect of these molecules. Eur. J. Pharmacol. 2012, 681, 34-43. [CrossRef] [PubMed]

164. Uguz, A.C.; Cig, B.; Espino, J.; Bejarano, I.; Naziroglu, M.; Rodriguez, A.B.; Pariente, J.A. Melatonin potentiates chemotherapy-induced cytotoxicity and apoptosis in rat pancreatic tumor cells. J. Pineal Res. 2012, 53, 91-98. [CrossRef] [PubMed]

165. Jung, J.H.; Sohn, E.J.; Shin, E.A.; Lee, D.; Kim, B.; Jung, D.B.; Kim, J.H.; Yun, M.; Lee, H.J.; Park, Y.K.; et al. Melatonin suppresses the expression of $45 \mathrm{~S}$ preribosomal RNA and upstream binding factor and enhances the antitumor activity of puromycin in MDA-MB-231 breast cancer cells. Evid.-Based Complement. Alternat. Med. 2013, 2013, 879746. [CrossRef] [PubMed]

166. Kosar, P.A.; Naziroglu, M.; Ovey, I.S.; Cig, B. Synergic effects of doxorubicin and melatonin on apoptosis and mitochondrial oxidative stress in MCF-7 breast cancer cells: Involvement of TRPV1 channels. J. Membr. Biol. 2016, 249, 129-140. [CrossRef] [PubMed]

167. Yun, S.M.; Woo, S.H.; Oh, S.T.; Hong, S.E.; Choe, T.B.; Ye, S.K.; Kim, E.K.; Seong, M.K.; Kim, H.A.; Noh, W.C.; et al. Melatonin enhances arsenic trioxide-induced cell death via sustained upregulation of Redd1 expression in breast cancer cells. Mol. Cell. Endocrinol. 2016, 422, 64-73. [CrossRef] [PubMed]

168. Lin, S.; Hoffman, K.; Gao, C.; Petrulionis, M.; Herr, I.; Schemmer, P. Melatonin promotes sorafenib-induced apoptosis through synergistic activation of $\mathrm{JNK} / \mathrm{c}$-jun pathway in human hepatocellular carcinoma. J. Pineal Res. 2017, 62, e12398. [CrossRef]

Sample Availability: Melatonin is commercially available.

Publisher's Note: MDPI stays neutral with regard to jurisdictional claims in published maps and institutional affiliations.

(C) 2020 by the authors. Licensee MDPI, Basel, Switzerland. This article is an open access article distributed under the terms and conditions of the Creative Commons Attribution (CC BY) license (http://creativecommons.org/licenses/by/4.0/). 